\title{
The epidemiology of acute childhood and adolescent poisoning in Thi-Qar governorate (2013-2015)
}

\author{
Dr-Raid Kareem Dehiol F.I.B.M.S. D.C.H. \\ raid.k@utq.edu.iq \\ Department of pediatrics, college of medicine, Thi-Qar university
}

\section{Abstract}

Background: acute childhood and adolescent poisoning remain one of the important emergencies causing a significant burden to the populations with important morbidity and mortality rates.

Objectives: This study aimed to determine the epidemiological features of poisoning for the patients less than 19 years old in Al-Nasiriyah governorate, and to eliminate the main types, clinical presentations, management, outcome, and seasonal variation of poisoning. Epidemiological studies are so important to determine the extent of the problem, according to which the preventive strategies are related.

Methods: A cross sectional retrospective study was conducted to three hundred forty patients recorded in Al-Nasiriyah poison center from (January 2013 to December 2015), data that collected from the case sheets and records of phone calls including the name, sex, address, type of poisoning, route of administration, management and the outcome of the patients (survive or died) are admitted to the SPSS (statistical package for social science) system and the results was obtained.

Results: two hundred (58.8\%) of the exposed patients was male, toddler age group seen in $45 \%$ of cases with predominance of accidental type, while adolescents (>13-18yrs.) are mostly intentional with female preponderance, urban populations are more prone to poisoning 236 cases (69.4\%), accidental exposure is the commonest $(83.2 \%)$ oral route is the commonest $(99.4 \%),(62.9 \%)$ of the causative agents are pharmaceutical, and $(50.3 \%)$ are asymptomatic . most of them treated conservatively (96.5\%) with survival rate of (97.9\%), higher mortality seen in those presented after the first $24 \mathrm{hrs}$. of exposure. One third of acute poisoning was occurred in summer season. Easy accessibility to the drugs and toxic substances are the major risk factor.

Conclusion: Although poisoning is a preventable illness but, it is still a significant cause of morbidity and mortality especially in developing countries. Acute poison has a significant impact on the health services.

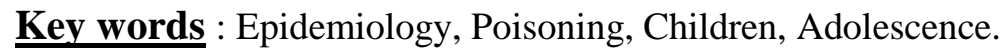




\section{Introduction:}

Acute poisoning is an important cause of morbidity and mortality among children and adolescents accounting for more than 1 million cases reported annually to the "Toxic Exposure Surveillance System" (TESS) of the "American Association of Poison Control Center" (AAPCC) (1). Recent data demonstrate that poisoning is the second leading cause of injury-related fatalities ${ }^{(2)}$. Poisoning is used to denote any exposure to any xenobiotic (drug, toxin, chemical, or naturally occurring substance) that results in injury ${ }^{(3)}$. Also childhood poisoning is the third common emergencies resulting in high social and economic burden, remaining one of the important medical problem and public health concern ${ }^{(4)}$. The high prevalence of poisoning in children is caused by the curiosity to their environment and to taste and swallow substances including harmful type ${ }^{(5)}$. Poisoning can be classified into two classes depending on the pattern of poisoning; intentional and non intentional (accidental) poisoning (6). Infants and children less than 5 years are frequently prone to accidental type. The childhood acute poisoning commonly Occur in the household (90\%) and the poisons are often domestic substances. Drugs are considered as the second most common ingested poisons ${ }^{(7)}$. Intentional poisoning mainly involves adolescents, predominantly girls

(8). It may be a result of whole sequences of stressful events in their life, family problems, romantic disappointment, lack of self acceptance, leading to negative emotional reaction that can provide thoughtless behavior and suicidal attempts ${ }^{(9)}$. Ingestion is the commonest route of poisoning in children, accounting for (77\%) of the cases followed by, dermal (7.5\%), inhalation $(6 \%)$ and ophthalmic route $(5 \%)^{(10)}$. In Iraq the first poison center was initiated in Baghdad at the last three decades, while Al- Nasiriyah poison center was opened at $2010^{(11)}$. At the last years the mortality caused by poisoning was decreased dramatically due to establishing poisons control centers in developed countries. Also early recognition of poisons exposure, early presentation to the medical services, and improved medical interventions can play an important role in the outcome of the patient $^{(12)}$.

Approximately three million of acute poisoning and 200,000 deaths annually reported around the world, caused by accidental or intentional exposure to pharmaceutical or non pharmaceutical substances ${ }^{(13)}$. Acute poisoning is a preventable illness and the mortality rate can be decreased dramatically by using effective prevention programs ${ }^{(14)}$. Poison is the substance that can cause damage or internal injury to the body cells result in toxication and endangers human life ${ }^{(15)}$. It has been found that the commonest risk factors for poison exposure are young age, female sex, large family size, low educational level of the patients or their parents, and low socioeconomic status ${ }^{(16)}$. In addition exposure to drugs, agrochemicals, and environmental poisons are the main cause of childhood and adolescent poisoning ${ }^{(17)}$. The most 
common agents ingested by young children include cosmetics, cleaning solutions, personal care products, analgesics, and plants. Fatal childhood poisoning is mainly caused by analgesics, antihistamines, sedative/hypnotics, plants, and fumes/vapors/gases ${ }^{(18)}$. Any child who presents with unexplained symptoms including altered mental status, seizure, metabolic abnormality, and cardiovascular compromise should be considered to have poisoning until proven otherwise. ${ }^{(18)}$. Epidemiological studies reveal the incidence of poisoning among children is $(0.74 \%-3 \%)$. About $80 \%$ of all cases in children occur in age (1-5) years, therefore; it is common in younger ages ${ }^{(19)}$. Acute childhood poisoning constitute $(2.3 \%)$ of all pediatric emergencies. And the overall mortality rate is $(3-5 \%){ }^{(20)}$. Management depend on the type of poisonous that exposed to, clinical presentation, and the duration between toxin exposure and the emergency unit admission ${ }^{(16)}$. Treatment can be started at home. In certain circumstances the child may admitted to the emergency unit were the assessment and stabilization of vital signs is done. Rarely, emergency management needs the administration of special antidote, or other measures to enhance the elimination of the absorbed toxins ${ }^{(21)}$. Laboratory analysis of serum or urine usually guided by the substance exposure, and its anticipated degree of toxicity, rarely toxicological screening tests done when the ingested substance is not identified ${ }^{(22)}$. Supportive care is the mainstay of treatment in most cases. If the level of consciousness is depressed, and a toxic substance is suspected, glucose ( $1 \mathrm{~g} / \mathrm{kg}$ intravenously), $100 \%$ oxygen, and naloxone should be administered ${ }^{(18)}$. Single-dose activated charcoal decreases drug absorption when used with in 1 hour of ingestion, wholebowel irrigation using polyethylene glycol (GOLYTELY) as a non absorbable cathartic may be effective for toxic ingestion of sustained-release entericcoated drugs ${ }^{(18)}$. Multiple-dose activated charcoal should be considered only if a patient has ingested a life threatening amount of carbamazepine, dapsone, phenobarbital, quinine, or theophylline. Alkalinization of urine may be helpful for salicylate or methotrexate ingestion ${ }^{(23)}$.

\section{The aims of this study are :-}

1- To identify the epidemiology of acute childhood and adolescent poisoning. (incidence, pattern of, clinical presentation, seasonal variation, and the determinants of poisoning).

2- To evaluate the management of poisoning and the patient's outcome.

Careful evaluation of the above facts will help us to determine the effective strategies that prevent acute childhood and adolescent poisoning and the proper time for medical intervention in order to minimizing the morbidity, and mortality of the illness at the same time.

\section{Materials and methods}

It is a retrospective cross sectional study carried out in Thi-Qar governorate from (January 2016 to September 2016). In 
which the researcher evaluate the medical records of Al-Nasiriyah poison center that include phone cases and case sheets of the patients for the last three years (2013, 2014, and 2015). All the medical information was obtained from these records like; chief complain, physical signs and symptoms, laboratory investigations that done in the hospital and the toxicological screen in the poison center, outcome of the patient, lines of management that taken in the hospital or those that instructed by the poison center, in addition to the demographic data including (age, sex, and address). Thi-Qar governorate is located in the southeast of Iraq. Thi-Qar province includes agricultural, industrial, residential, and business regions consisting a total area of $12900 \mathrm{~km}$. and a total population of $(1,979,561)$ persons in $2014(52 \%)$ of them are male and (48\%) was female, distributed in $(37,1 \%)$ rural and $(62,9 \%)$ urban area ${ }^{(24)}$.

Age groups that involved in this study were ranged from (1 month-18 years) divided into 5 groups as the following:

- $\quad$ Less than one year (infancy).

- Toddlers (>1-3) years.

- $\quad$ Preschooler (>3- 6) years.

- $\quad$ Schooler age $(>6-13)$ years.

- $\quad$ Adolescent $(>13-<19)$ years.

Type or the pattern of poisoning was divided as: (Intentional type, Non intentional type). The routes of administration were divided into: (oral, inhalational, and dermal). Time of presentation to the hospital divided to: (less than $24 \mathrm{hrs}$ and more than $24 \mathrm{hrs}$ ). Clinical presentations of the poisoned were patients classified according to the major system involved, multiple systems involvement, and asymptomatic cases. Type of poisonous (toxic substance) was divided to:- Pharmaceutical agents, Non pharmaceutical agents. Furthermore pharmaceutical agents were divided into:Analgesia, Antibiotics, Anti hypertensive agents, Anti histamine and anti-tussives, Psychotropic agents, Anticonvulsants, Iron preparations, and Oral contraceptive pills. Others (thyroxin, warfaren, anti spasmine, ventolin, calamine, multivitamins, atropine drop, dostenix, thyphline, atarax, laxatives, and sodium bicarbonates) according to the calculated data. Some patients presented with multiple agents poisoning. Also non pharmaceutical agents subdivided into:Toxic plants including mushroom and Datura ( palladona ), Pesticides including, Industrial chemicals like (hydrogen peroxides, naphthalene and thinner), Household products including, Others like (printer dye). Lines of treatment were divided into four groups: Conservative treatment (monitoring of the vital signs, intravenous fluid, gastric empting, and intestinal decontamination), Using of specific anti dots, Mixed treatment, or in some instances the patient not receive any treatment. Outcome of the patient was evaluated either survive or dead. Also the seasonal variation of poisoning was noted.

All the collected data was analyzed by using SPSS (Statistical Package for Social Science) system, and presented by proper tables and graphs. 


\section{RESULTS}

In this study more than a half of the population is male $200(58.8 \%)$ while female represent 140 cases $(41.2 \%)$.

(Table 1) The frequencies of age group, sex, and address of the patients.

\begin{tabular}{|c|c|c|}
\hline Variable & & Percent \\
\hline Age group & Frequency & 3.2 \\
\hline Tess than one year & 11 & 45.9 \\
\hline Preschooler & 156 & 25 \\
\hline Schooler & 85 & 8.8 \\
\hline Adolescents & 30 & 17.1 \\
\hline Gender & 58 & \\
\hline Male & 200 & 58.8 \\
\hline Female & 140 & 41.2 \\
\hline Residence & & \\
\hline Urban & 236 & 69.4 \\
\hline Rural & 104 & 30.6 \\
\hline Total & 340 & 100 \\
\hline
\end{tabular}

(Table 2) Sex distribution according to the age groups and residence of populations.

\begin{tabular}{|c|c|c|c|c|}
\hline \multirow{2}{*}{$\begin{array}{c}\text { Variable } \\
\text { Age groups }\end{array}$} & \multicolumn{2}{|c|}{ Sex } & $\begin{array}{c}\text { (\%)of total } \\
\text { population }\end{array}$ & \multirow{2}{*}{$\begin{array}{c}\text { Chi-seq. } \\
\text { P. Value }\end{array}$} \\
\cline { 2 - 4 } Less than one year & $7(63.6 \%)$ & $4(36.4 \%)$ & 3.2 & \\
\hline Toddlers & $110(70.5 \%)$ & $46(29.5 \%)$ & 45.9 & 51.886 \\
\hline Preschooler & $58(68.2 \%)$ & $27(31.8 \%)$ & 25 & \multirow{2}{*}{0.001} \\
\hline Schooler & $14(46.7 \%)$ & $16(53.3 \%)$ & 8.8 & \\
\hline Adolescent & $11(19 \%)$ & $47(81 \%)$ & 17.1 & \\
\hline Total & $200(58.1 \%)$ & $140(41.2 \%)$ & 100 & \\
\hline Residence & & & & 0.271 \\
\hline Rural & $59(56.7 \%)$ & $45(43.3 \%)$ & 30.6 & 0.603 \\
\hline Urban & $141(59.7 \%)$ & $95(40.3 \%)$ & 69.4 & \\
\hline Total & 200 & 140 & 100 & \\
\hline
\end{tabular}


(Table 3) Differences in the pattern of poisoning according to age groups, sex and type.

\begin{tabular}{|c|c|c|c|c|}
\hline Variable & \multicolumn{2}{|c|}{ Pattern of poisoning } & \multirow{2}{*}{$\begin{array}{l}\text { (\%) of total } \\
\text { population }\end{array}$} & \multirow{2}{*}{$\begin{array}{l}\text { Chi-seq. } \\
\text { P value }\end{array}$} \\
\hline Age groups & Intentional & Non int. & & \\
\hline Less than one year & $0(0.0 \%)$ & $11(100 \%)$ & $3.2 \%$ & \multirow{3}{*}{180.269} \\
\hline Toddlers & $2(1.3 \%)$ & $154(98.7 \%)$ & $45.9 \%$ & \\
\hline Preschooler & $3(3.5 \%)$ & $82(96.5 \%)$ & $25 \%$ & \\
\hline Schooler & $9(30 \%)$ & $21(70 \%)$ & $8.8 \%$ & \multirow[t]{2}{*}{0.001} \\
\hline Adolescent & $43(74.1 \%)$ & $15(25.9 \%)$ & $17.1 \%$ & \\
\hline Total & 57 & 283 & $100 \%$ & \\
\hline \multicolumn{5}{|l|}{ Sex } \\
\hline Male & $13(6.5 \%)$ & $187(93.5 \%)$ & $58.8 \%$ & \multirow{2}{*}{$\begin{array}{c}36.675 \\
0.001\end{array}$} \\
\hline Female & $44(31.4 \%)$ & $96(68.6 \%)$ & $41.2 \%$ & \\
\hline Total & 57 & 283 & $100 \%$ & \\
\hline \multicolumn{5}{|l|}{ Type of poison } \\
\hline Pharmaceutical & $33(15.4 \%)$ & $181(84.6 \%)$ & $62.9 \%$ & \multirow{3}{*}{$\begin{array}{l}0.748 \\
0.387\end{array}$} \\
\hline Non pharmaceutical & $24(19 \%)$ & $102(81 \%)$ & $37.1 \%$ & \\
\hline Total & 57 & 283 & $100 \%$ & \\
\hline
\end{tabular}

(Table 4) The proportions of pharmaceutical agents according to pattern of poisoning.

\begin{tabular}{|c|c|c|c|c|}
\hline \multirow{2}{*}{$\begin{array}{c}\text { Variable } \\
\text { Pharmaceutical }\end{array}$} & \multicolumn{2}{|c|}{ Pattern of poisoning } & $\begin{array}{c}\text { Percent from } \\
\text { total }\end{array}$ & $\begin{array}{c}\text { Fisher's test, } \\
\text { P value }\end{array}$ \\
\cline { 2 - 4 } Antihistamine,Antitusive & $4(12.1 \%)$ & $39(21.5 \%)$ & $20.1 \%$ & \\
\hline Psychotropics & $5(15.2 \%)$ & $23(12.7 \%)$ & $13.1 \%$ & \\
\hline Analgesics & $4(12.1 \%)$ & $17(9.4 \%)$ & $9.8 \%$ & \multirow{2}{*}{10.724} \\
\hline Anti convulsant & $2(6.1 \%)$ & $16(8.8 \%)$ & $8.4 \%$ & \multirow{2}{*}{0.124} \\
\hline Oral contraceptive & $1(3 \%)$ & $12(6.6 \%)$ & $6.1 \%$ & \\
\hline Antihypertencive & $1(3 \%)$ & $10(5.5 \%)$ & $5.1 \%$ & \\
\hline Iron complements & $1(3 \%)$ & $7(3.9 \%)$ & $3.7 \%$ & \\
\hline Antibiotics & $0(0 \%)$ & $4(2.2 \%)$ & $1.9 \%$ \\
\hline Others & $7(21.2 \%)$ & $42(23.2 \%)$ & $22.9 \%$ & \\
\hline Multipe agents & $8(24.2 \%)$ & $11(6.1 \%)$ & $8.9 \%$ & \\
\hline Total & $33(100 \%)$ & $181(100 \%)$ & $100 \%$ & \\
\hline
\end{tabular}

(Table 5) The proportions of non pharmaceutical agents according to the type of poisoning.

\begin{tabular}{|l|l|l|l|l|}
\hline \multirow{2}{*}{$\begin{array}{l}\text { Variable } \\
\text { Non pharmaceutical }\end{array}$} & \multicolumn{2}{|l|}{ Pattern of poisoning } & $\begin{array}{l}\text { Percent of } \\
\text { total }\end{array}$ & $\begin{array}{l}\text { Fisher's test, } \\
\text { P value }\end{array}$ \\
\cline { 2 - 4 } Pesticides & Intentional & Nonintentional & $58.7 \%$ & \\
\hline Plants & $17(70.8 \%)$ & $57(55.9 \%)$ & 10.988 \\
\hline Houshold products & $6(25 \%)$ & $17(16.7 \%)$ & $18.3 \%$ & \\
\hline
\end{tabular}


Thi-Qar Medical Journal (TQMJ): Vol.(14), No.(2), 2017

Email:utjmed@utq.edu.iq

Web Site: https://imed.utq.edu.iq

\begin{tabular}{|l|l|l|l|l|}
\hline Industrial chemicals & $0(0 \%)$ & $9(8.8 \%)$ & $7.1 \%$ & \multirow{2}{*}{0.031} \\
\hline Others & $1(4.2 \%)$ & $3(2.9 \%)$ & $3.2 \%$ & \\
\hline Total & $24(100 \%)$ & $102(100 \%)$ & $100 \%$ & \\
\hline
\end{tabular}

Figure (1) Route of exposure

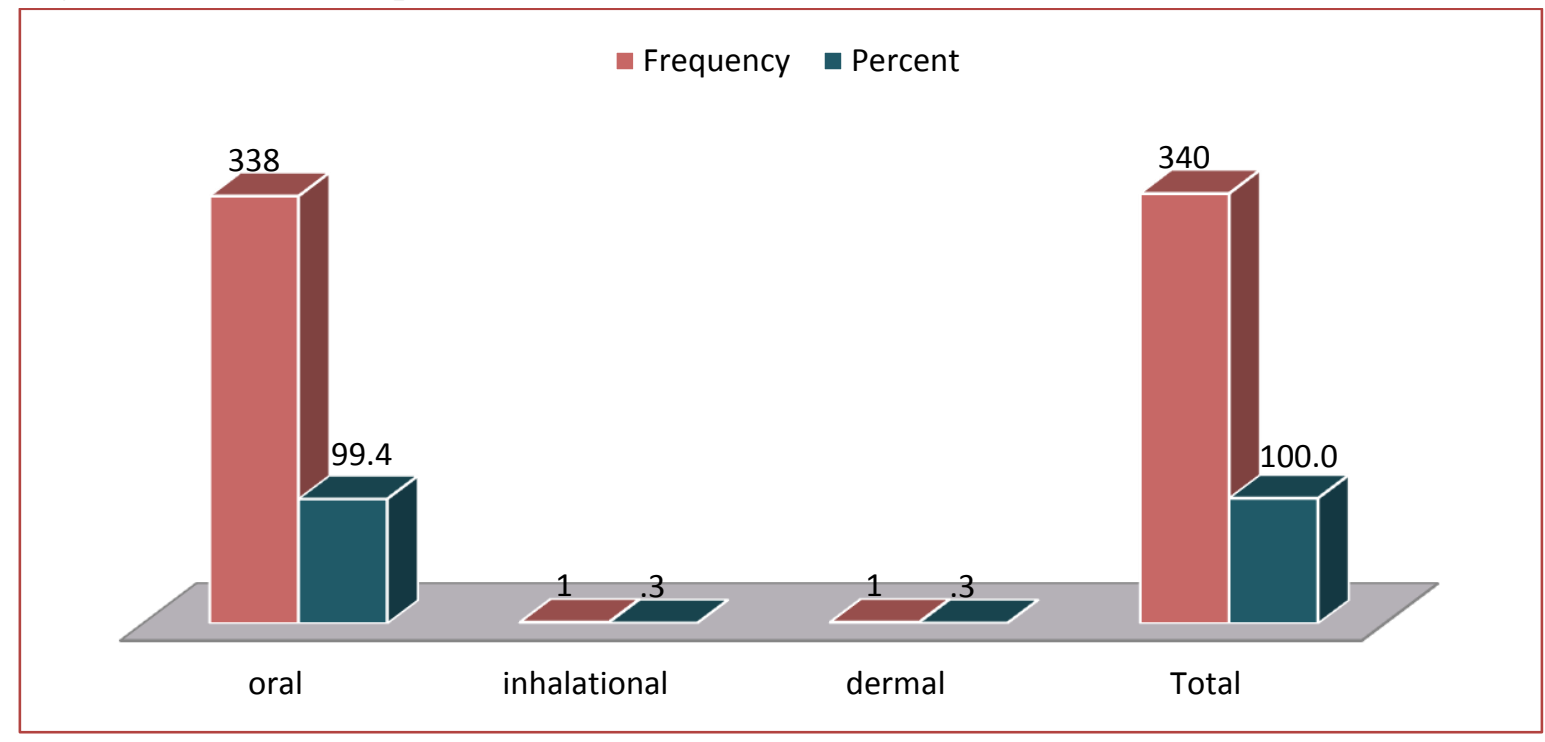

(Figure 2) Clinical presentations of acute childhood and adolescent poisoning.

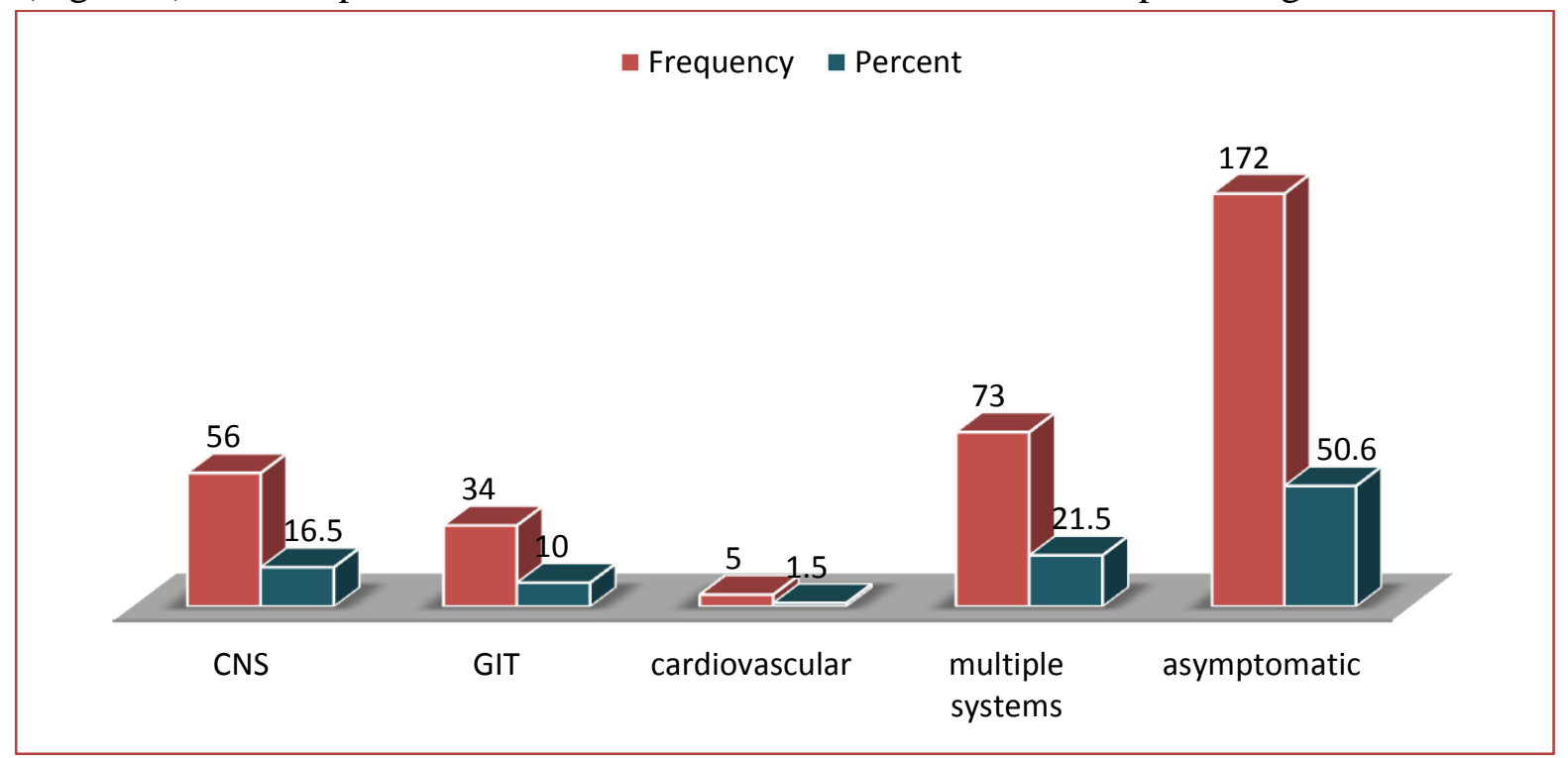


Thi-Qar Medical Journal (TQMJ): Vol.(14), No.(2), 2017

(Table 6) The effects of presenting time to the hospital and type of management on the outcome of the exposed patients.

\begin{tabular}{|c|c|c|c|c|}
\hline \multirow{2}{*}{$\begin{array}{c}\text { Variable } \\
\text { Time of presentation }\end{array}$} & \multicolumn{2}{|c|}{ Outcome } & Percent from & Chi-square, \\
total & P value \\
\hline Before 24 hours & $332(99.8 \%)$ & $4(1.2 \%)$ & $98.8 \%$ & 106.797 \\
\hline After 24 hours & $1(25 \%)$ & $3(75 \%)$ & $1.2 \%$ & .001 \\
\hline Type of treatment & & & & \\
\hline Conservative & $325(99.1 \%)$ & $3(0.9 \%)$ & $96.5 \%$ & 111.996 \\
\hline Anti dotes & $1(25 \%)$ & $3(75 \%)$ & $1.2 \%$ & 0.001 \\
\hline Mixed & $7(87.5 \%)$ & $1(12.5 \%)$ & $2.4 \%$ & \\
\hline
\end{tabular}

(Figure 3) Seasonal variation of poisoning.

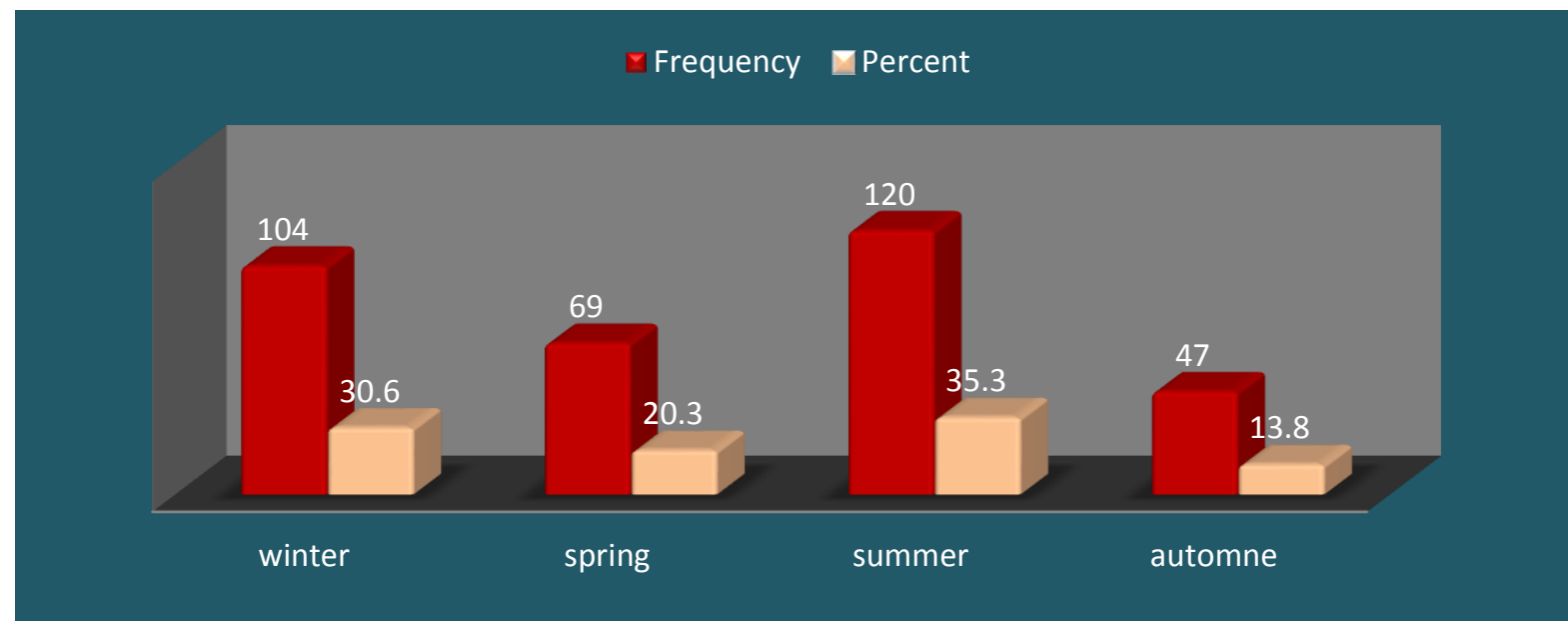

\section{Discussion:}

At present study more than one half of exposed population are male across all the age groups (58.8\%), except in adolescents (14-18yrs.) which showed gender reversal, that in agreement with other studies at Costa Rica and Spain ${ }^{(25-26)}$. Hyperactivity of the male and restless in compare with female is responsible factors. The more prevalent age group is toddlers (45.9\%), followed by preschooler, adolescents, schooler, and infants, similar to other studies in Japan, and
Costa Rica ${ }^{(25,27)}$ Child curiosity, oral exploratory (mouthing habit), and newly acquired hand skills, are the main causes for this

predominance. Approximately two thirds (69.4\%) of exposed patients are from urban population, similar to single center study in Poland at 2011 that reveal $(64.50 \%)$ of poisoned patients came from urban area ${ }^{(4)}$, this fact may be due to easy accessibility and direct admission 
to the hospitals in urban population. O'Connor et al. study and Basheir study (in Australia and Egypt respectively) was not agreed with current study showing the high incidence of poisoning in rural areas ${ }^{(28,29)}$. Accidental type is the most common type of childhood and adolescent poisoning $(83.2 \%)$, and intentional type (16.8\%), male gender at toddler and schooler age groups are predominant in accidental type, while adolescent female are the predominant of intentional type as a result of self intoxication, the incidence of accidental poisoning (non intentional) decreased as the age increased (inverse correlation), and the incidence of intentional type increased as the age of children increased. In addition, there was a significant relationship between the pattern of poisoning, age, and sex $P$ value $=0.001$, as presented by our

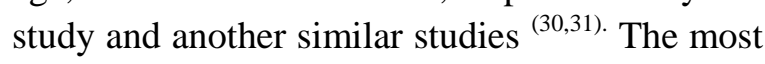
probable causes of self intoxication are; depressive illnesses, self disappointment, romantic, family, and school problems, drug abuse are also a considerable cause.

In our study we identified eight most common pharmaceutical poisons accounting for (62.9\%) of exposed population and four commonest non pharmaceutical substances consisting a $(37.1 \%)$. Antihistamine-antitussive group is the commonest $(20.1 \%)$ followed by Psychotropics and analgesia, explaining the availability and easy accessibility of over the counter drugs along with un proper usage and storage of psychotropics. In contrast antibiotics are the least that involved in medicinal type of poisoning, our findings are partially agreed with (29) study that found the predominant medications are neurological and analgesics where over-the-counter drug is the third one. Among non pharmaceutical substances; pesticides are the commonest $(58.7 \%)$ followed by plants and household products agreed with Akhtar et al. ${ }^{(32)}$, while not agree with another previous studies showed that cleansing agents were the main cause of poisoning in children and that pesticides the least one ${ }^{(33,34)}$. This discrepancy explained by agricultural nature of Thi-qar where pesticides are available in most houses. Among pharmaceutical agents; psychotropics are the commonest that found in intentional poisoning, agreed with Yan-Ren study in Taiwan (35), while antihistamineantitussives are the commonest in accidental type, furthermore pesticides are the most prevalent one from non pharmaceutical group in both types of poisoning, not similar to ${ }^{(35)}$ that show cleansing products are the most common in intentional type, with no statistically significant differences in pharmaceutical agents, $P$. value $=(0.124)$, while there are statistically significant differences in non pharmaceutical substances, $\mathrm{P}$ value $=(0,031)$. In addition $(8.9 \%)$ of our population exposed to multiple agents similar to Lee it al. study ${ }^{(36)}$ while the majority $(91.1 \%)$ exposed to single agent which was in agreement with Hon et al. study ${ }^{(37)}$.

More than half $(50.6 \%)$ of the exposed patients presented asymptomatically to the emergency department just with history of exposure, this may be due to bad taste of poisonous substances lead to ingestion of very small amount, or may be due to induction of vomiting by the family at home or early presentation to the hospital. This finding was less than that reported by Kholod D.H that found $62.5 \%$ of patients asymptomatic ${ }^{(38)}$. By the other hand $(16.5 \%)$ of cases presented with neurological symptoms including (drowsiness, blurred vision, confusion, and even coma), (10\%) gastrointestinal presentation (nausea, vomiting, and abdominal pain), additionally; $(21.5 \%)$ presented with multiple signs and symptoms, which in agreement with ${ }^{(29,35)}$. Oral route is the predominant in all cases of poisoning followed by inhalational and dermal route, which is in agreement with Liebet ${ }^{(10)}$. In our study $(98.8 \%)$ of the patients presented at 
the first $24 \mathrm{hrs}$. treated properly and discharged, with mortality rate of only $(1.2 \%)$, while $(75 \%)$ of patients that presented after the first $24 \mathrm{hrs}$. are died, these observations were similar to Sabiha S. et. al. study ${ }^{(39)}$. Death occur more in psychotropic poisoning (pharmaceutical agents) similar to ${ }^{(40)}$, while plants are the commonest in non pharmaceutical group in contrast to another finding of ${ }^{(40)}$ that found the pesticides are the main causative substance of death in childhood poisoning, followed by industrial chemicals. In current study the highest incidence of poisoning was in summer $(35.3 \%)$, followed by winter $(30.6 \%)$, that in partial agreement with Majid study that present a highest incidence of poisoning in summer season followed by spring ${ }^{(41)}$. High prevalence of poisoning in summer and winter might be due to the more time that expend by the child was in door along with availability, easy accessibility, and un safe storage of various xenobiotics in home. The mortality rate of acute childhood and adolescent poisoning ranges from $7.6 \%$ to $0.4 \%$ in literature ${ }^{(42)}$, in our study 7 cases $(1.2 \%)$ was died for the three years of our populations. Relatively this good prognosis attributed to early presentation to the emergency unit, early measures in home such as induction of vomiting and availability of poison centers along with proper medical interventions. Limitations in this study are mainly due to retrospective nature, and the accuracy of data depend on the data collectors that may have a misclassification to the medical information such as pattern of poisoning, so a potential bias might be developed. Another important limitation is lack of kerosene and snake venom poisoning that not sent to the poison center from the emergency departments, that's why we exclude kerosene and snake venom poisoning from our study.

\section{Conclusion:}

- Accidental poisoning was more frequent in toddlers and preschooler males. While Intentional poisoning was increased with increasing age of child to being at more risk in schooler and adolescent females as compared with male.

- Although about half of the exposed patients are asymptomatic, the others presented with CNS, GIT, and multiple symptoms.

- Vast majority of cases presented to the causality within the first $24 \mathrm{hrs}$. of exposure and treated conservatively. Higher mortality seen in those presented after the first $24 \mathrm{hrs}$. of exposure.

- Easy accessibility to the drugs and toxic substances are the major risk factor, and poison information centers play a vital role in the management of acute poisoning.

\section{Recommendations:}

- $\quad$ All the poisonous substances and drugs should be kept in their original container and out of reach of children, food and drink containers should never be used for the excess of xenobiotics.

- Xenobiotics should be kept with non lethal concentrations.

- Parents should buy or accept medications only if it is in a child-resistant container.

- $\quad$ Training the families about the early managements of exposed patient and early consultations in order to reduce the morbidity and mortality.

- Appropriate public educational programs about safe practice of storing medications and toxic household substances, and earlier educational programs in the secondary schools for adolescent female regarding the hazards of poisoning and self intoxication.

- Further prospective epidemiological studies are required for further exploration of acute poisoning illness. 
Thi-Qar Medical Journal (TQMJ): Vol.(14), No.(2), 2017

Email:utjmed@utq.edu.iq

Web Site: https://jmed.utq.edu.iq

\section{References:-}

1. Vazirian S, Mohamad Nejad M, Moqadasi A. poisoning epidemiology between admitted children in Razi and Shahid fahmideh hospitals in Kermanshah during 2002-2003 year. Kermanshah Med Uni J 2004; 8 (2): 29-36.

2. Centers for Disease Control and prevention (CDC). Increases in age groupspecific injury mortality-united states, 1999_2004. MMWR Morb Mortal Wkly Rep. 2007; 56:1281-1284.

3. Gold Franks. Toxicologic Emergencies: Ninth ed., pp. 1790; 2011 Mc Graw Hill.

4. Elzbieta et al. Pattern of poisoning in urban and rural children: A single- center study. Adv Clin Med 2016; 25(2): 335-340.

5. G. C. Rodgers, Jr, et al. "poisonings" in Nelson's Textbook of pediatrics, R. M. Kliegman, R.E. Behrman, H.B. Jenson, and B.F. Stanton, Eds. Saunders: Elsevier, , Philadelphia; 2008: 339-357.

6. Zawadzka-Gralec A, Zielin'ska-Duda H, Czerwionka-Szaflarskam, Wegrzynowska E, Kurylak D, Siwkas, Pufal E, BlochBoguslawska E, Sliwkak. Acute poisoning in children and Adolescent. Pediatr pol 2008; 83:373-379.

7. Bronstein Ac, Spyker DA, Cantilena LR Jr, Green JL, Rumack BH, Ciffin SL.2008 Annual Report of the American Association of Poison Control Centers National Poison Data System (NPDS): 26 ${ }^{\text {th }}$ Annual Report. Clin Toxicol (phila) 2009; 47 (2): 911-1084.

8. Lamireau $\mathrm{T}$, Lianas $\mathrm{B}$, Kennedy A, Fayon M, Penouil F, Faverell-Garrigues Jc, Demarquez JL. Epidemiology of poisoning in children: A 7 year Survey in a pediatric emergency care unit. Eur J Emerg Med 2002; 9: 9-14.

9. Bukawska W, Szlagatys A, Korzon M: Intoxication in children and adolescents-new problems. Przegl Pediatr 2001; 31: 50-54.
10. Liebelt EL, De Angelis CD. Evolving trends and treatment advances in pediatric poisoning. JAMA 1999; 282 (12): 1113-15.

11. Iraq. Ministry of health / Planing directore, 219: 2010.

12. Winchester JF, Harbord NB, Rosen H. Management of poisonings: Core Curriculum 2010. Am J Kidney Dis 2010; 56 (4): 788-800. 13. Reith DM, Pitt WR, Hockey R. Childhood poisoning in Queensland: An analysis of presentation and admission rates. $\mathbf{J}$ Pediatr Child Health 2001; 37: 446-450.

14. Hockey R, Reith D, Miles E. Childhood Poisoning and ingestion. Injury Bull 2000; 60: 1-6.

15. Thomas WF, John HD, William RH. Stedman's medical Dictionary. $28^{\text {th }}$ ed. New York: Lippincott William and Wilkins; 2007. P. 2004.

16. Nhashi CF, Kasilo OM. The Pattern of poisoning in urban Zimbabwe. J Appl Toxicol 1992; 12: 435-438.

17. Hampe stead K. Manner of death and circumstances in fatal poisoning: Evidence from New Jersey. Injury prevention 2006; 12: 44.

18. Karen J. Marcdante, Robert M. Kliegman. Nelson's, Essential of pediatrics, Elsevier Saunders; Canda, $7^{\text {th }}$ ed: 2013: 139144.

19. Sahin S, Carman KB, Dinleyici EC. Acute poisoning in children; data of a pediatric emergency unit. Iran J Pediatric. 2011; 21: 479-84.

20. Halak Vasavada, Pankti Desai. Clinical Profile And outcome of Children presenting with poisoning $\mathrm{C} \mathrm{H}$ Hospital Based Study. NJIRM. 2013; 4:1-7.

21. Hjern A, Ringback-weitoft G, Anderson R. Sociodemographic risk factors for hom-type injuries in Swedish infants and toddlers. Acta pediatric 2001; 90: 61-68. 
Thi-Qar Medical Journal (TQMJ): Vol.(14), No.(2), 2017

Email:utjmed@utq.edu.iq

22. Belson MG, Simon H K. Utility of comprehensive toxicologic screens in children. Am J Emerg Med 1999; 17: 221-4.

23. Kivisto JE, Arvola T, Parkkari J, Mattila VM: Pediatric poisoning treated in one finish main university hospital between 2002 and 2006. Acta pediatric 2008;97: 790-94.

24. Iraq. Ministry of Planning / Central Statistic Organization. Annual report 2014.

25. YR leveridge: the pattern of poisoning in costa Rica during 1997, Vet Hum Toxicol 41, 100-102 (1999).

26. M R Repetto: Epidemiology of poisoning due to pharmaceutical products, Poison Central Center, Seville, Spain. Eur J Epidemiology. 1997; 13: 353-356.

27. K Goto, $\mathrm{Y}$ Endoh, $\mathrm{Y}$ Kuroki and $\mathrm{T}$ Yoshioka: poisoning in children in Japan. Ind $\mathrm{J}$ Pediatric 1997; 64: 461-68 .

28. P. J. O'connor, Differentials in poisoning rates of young Australian children according to residential location and geographical remoteness, Injury prevention 2005;11(4): 204-206.

29. Basheir A, Hassan and Mohamed G. Siam: Pattern of Acute poisoning in childhood in zagazig, Egypt: An Epidemiological study. Hindawi Publishing Corporation, International Scholarly Research Notices 2014, Article ID 245279, 5 pages, 10.1155/2014/245279.

30. Nordentoft M. Prevention of suicide and attempted suicide in Denmark. Epidemiological studies of suicide and intervention studies in selected risk groups. Dan Med Bull 2007; 54: 306-369.

31. Farzaneh E, Mehrpour O, Alfred S, Monghaddam HH, Behnoush B, Seghatoleslam T. Self-poisoning suicide attempts among students in Tehran, Iran. Psychiatry Danub 2010; 22: 34-38.

32. Akhtar, R. G. Raj, and F. Al-Anezi,

"Risk factors in acute poisoning in children: a retrospective study", Kuwait medical Jaurnal,2006; vol. 38: 33-36.

33. Andrian N, Sarikayalar F, Pattern of acute poisoning in childhood in ankara: what has changed in twenty years? Turk J Pediatric 2004; 46: 147-152.

34. Mentegi S, Fernandez A, Alustiza J, Canduela V, Mongil I, Caubet I, et al, Emergency visitsfor childhood poisoning: a 2year prospective multicenter survey in Spain, pediatric Emergency care 2006; 22:334-338.

35. Yan-Ren Lin, Tung-kung Wa, Tzu-An Liu, Chu-chung chou, Han-ping Wu, Poisoning Exposure and outcome of children admitted to a pediatric emergency department, Taiwan, china, changhua. World J Pediatr 2011;7(2):143-149

36. H.-L. lee, H.-J. Lin, S-Y Yeh, C.-H Chi, and H.-R Guo, "Etiology and outcome of patients presenting for poisoning to the emergency department in Taiwan: a prospective study, Human and Expiremental Toxicology.2008; 27(5) : 373-379.

37. K. L. Hon, J. K. Ho, T. F. Leung, Y. Wong, E. A. Nelson, and T. F, Fok, "review of children hospitalized for ingestion and poisoning at a tertiary center, Annals of the academy of medicine, 2005; 34(5): 356-361.

38. Kholod D. H., A three year review of accidental poisoning in children at Fatema ALZahra Teaching Hospital, Baghdad. The Iraqi postgraduate medical journal. 2006; Vol. 5, No. 3: 431-434.

39. Sabiha Sahin, M D, Kursat Bara Carman $\mathrm{MD}$, and Ener Cargi Dinleyici, MD, acute poisoning in children; Data of pediatric Emergency unit, Iran J pediatric, Dec 2011; vol. 21(no. 4): 479-484.

40. Tetas Praiapati, et al. Acute chemical and pharmaceutical poisoning cases treated in Civil Hospital, APJMT 2; 2 June 2013. 
Thi-Qar Medical Journal (TQMJ): Vol.(14), No.(2), 2017

Web Site: https://imed.utq.edu.iq

41. Majid Abdul Wahab Maatook, Pattern of acute poisoning in children. Medical Journal of Babylon. 2014; vol. 11; no. 3:512-517.

Karadeniz region between 2002-2006: increased suicide poisoning. Hum Exp Toxicol 2010; 29(2):131.

42. Mutlu M, Gansu A, Karakas T, et al.

Pattern of pediatric poisoning in the east

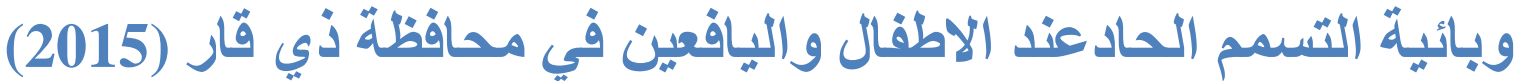

$$
\text { الدكتور رائد كريم دهيول }
$$

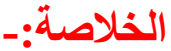

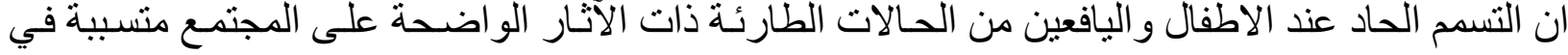
تز ايد حالات المر اضة و الوفيات بين تللك الفئات.

الالهد|ف:-

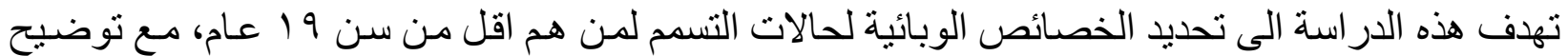

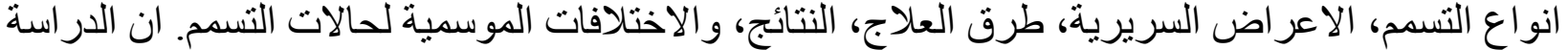

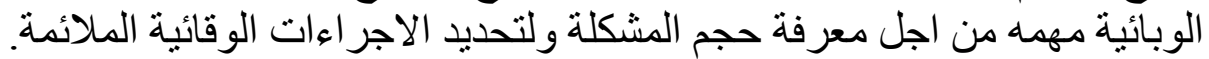

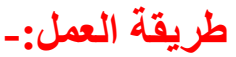
در اسه مقطعيه شملت ثنلاثمائة واربعون حالة تسمم اخذت من ملفات المرضـى وسجاتلات المركز الاستشـاري

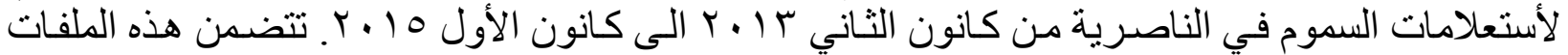

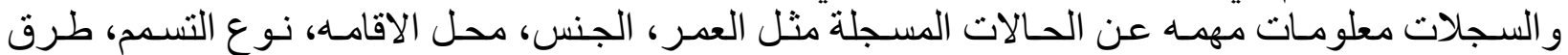
المعالجة، وكذللك النتائج. تم تحليل تللك المعلومات و واستخر اج النتائج الاحصائية منها.

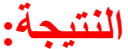

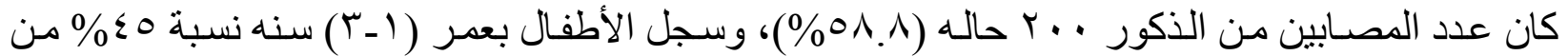

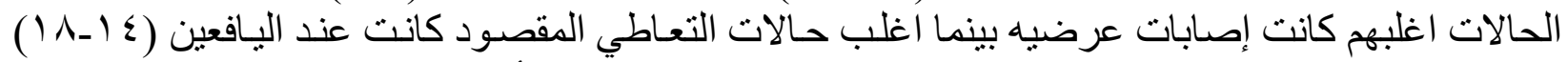

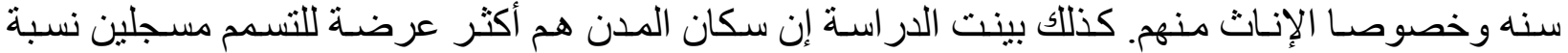

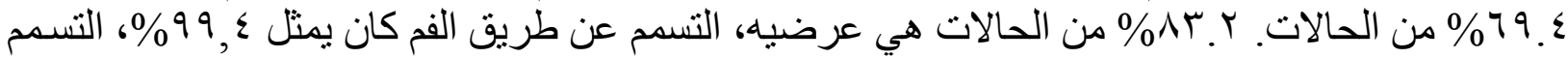

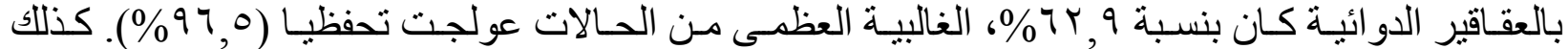

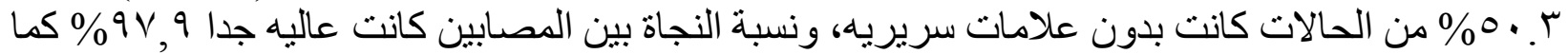

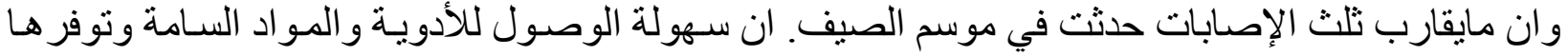
في المنازل من العوامل المهمة لتز ايد حالات التسمح.

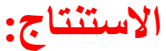


Thi-Qar Medical Journal (TQMJ): Vol.(14), No.(2), 2017

Email:utjmed@utq.edu.iq $\quad$ Web Site: https://jmed.utq.edu.iq

رغم إن التسمم من الحالات التي يمكن تلافيها والتوقي منها إلا أنها تبقى من الأسباب المهــة لتز ايد حالات

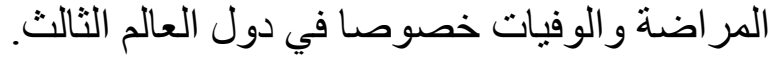

